\title{
Health Communication in Local Perspective (Critical Study of the Cultural Effects on the Healthy Lifestyle of Communities on the Flores Island)
}

\author{
Yonas Klemens Gregorius Dori Gobang ${ }^{1} \&$ Frans Salesman ${ }^{2}$ \\ ${ }^{1}$ Lecturer in Communications Science in the University of Nusa Nipa Flores East Nusa Tenggara Indonesia \\ ${ }^{2}$ Profesor at Public Health Science in Citra Bangsa University Kupang-East Nusa Tenggara Indonesia \\ Correspondence: Frans Salesman, Profesor at Public Health Science in Citra Bangsa University Kupang-East \\ Nusa Tenggara Indonesia. Scopus ID: 57205682025. Web of Sciences ID: Q-3001-2018. E-mail: \\ franssalesman@gmail.com
}

Received: January 9, 2020 Accepted: February 21, 2020Online Published: February 25, 2020

doi:10.5539/gjhs.v12n3p148

URL: https://doi.org/10.5539/gjhs.v12n3p148

\begin{abstract}
Traditional societies have cultural wisdom to maintain their health, and care for themselves when sick. Purpose.reveal the facts, circumstances, phenomena of Cultural Influence on the Healthy Lifestyle of Communities on the Island of Flores, East Nusa Tenggara. Method.Qualitative descriptive, by uncovering the facts as they are, interpreted and concluded.Results. The traditional community's belief in Flores that health and sickness is determined by an invisible supernatural power. Worship is done through traditional rites to keep the community healthy, or to do spell prayers by the traditional healer in the process of healing the patient. Communication during health care uses traditional methods based on local culture. Their hope is that medical staff will also use local wisdom-based health communication patterns in modern medical care. Conclusion. Medical staff need to study local culture-based health communication in the modern health service process. In the future, it is necessary to include strategies and development of local culture-based health communication in medical care for patients in Indonesia.
\end{abstract}

Keywords: health communication, culture, local perspective, sick-health

\section{Introduction}

The name of Flores, from Portuguese means "flower" is an island located in the administrative area of the Province of East Nusa Tenggara, Indonesia. The name Flores comes from the Portuguese language "cabo de flores" meaning "Cape of flowers". The name Flores has been officially since 1636 by the Governor of the Netherlands East Indies named HendrikBrouwer. A study by Orinbao (1969) revealed that the real name of the island of Flores is Nusa Nipa (snake island) which from an anthropological perspective, this term is more useful because it contains various philosophical, cultural, and ritual traditions of the Flores people. The Flores ethnic group is an ethnic mix between Malays, Melanesians and Portuguese. Once a Portuguese colony, interaction with Portuguese culture was strongly felt in Flores culture, both through genetics, religion and culture. Some tribes inhabit Flores Island; Manggarai, Riung, Ngada, Nagekeo, Ende, Lio, and Sikka. The cultural differences between the Riung, Ngada, Nage-Keo, Ende, Lio and Sikka sub-tribes are not very large. However, the difference between the sub-ethnic group and the Manggarai people is large. As in terms of physical form, there is one striking difference. The population of Flores starting from the Riung people to the East shows more Melanesian characteristics, such as the population of Papua, while the Manggarai people show more Mongoloid-Malay characteristics. The Larantuka sub-tribe is different from the others. This is because they are more mixed with the influence of cultural elements from other Indonesian ethnic groups who come and mix in the city of Larantuka (Wikipedia,2020).

According to traditional Flores beliefs, health and sickness experienced by someone is caused by influences from outside oneself, including spirits who are always present with the community.

An important element of the religious element of the population of Flores, is belief in the Supreme Deity. In the Manggarai people the deity is called Mori Karaeng, while in the Ngada community it is called Deva. In the mythological community Manggarai Mori Karaeng is considered the creator of nature and there are special tales about how to create this earth, humans, the world of spirits, animals, and plants such as rice and corn. Whereas 
there are also fairy tales why it causes wind, earthquakes, why it punishes the moon with a lunar eclipse, and how it uses lightning to punish the jinn. There are also some tales that tell or explain how he helped people (Anonim, 2018), punished those who broke customs, and those who sinned for killing, opposing parents, or for ignoring their obligation to perform ceremonies.

The medical treatment efforts of the ethnic groups in Flores are carried out through the reading of mantras by shamans (rawin and atambeko in Manggarai) to ask to be kept away from various diseases as a form of local and primitive health communication. While the efforts of a group of people in various big cities in Indonesia who flocked to Singapore to seek treatment, indicated that health communication in a modern country like Singapore can influence human behavior to find better, more sophisticated, more modern health care alternatives.

The purpose of this study is to uncover the facts, circumstances, phenomena of Cultural Influence on the Healthy Lifestyle of Communities on the Island of Flores relating to traditional care patterns in accordance with the traditional beliefs of the people of Flores, East Nusa Tenggara.

\section{Methodology}

The method used in this research is descriptive qualitative method. This type of research whose findings are not obtained through statistical procedures or other forms of calculation. The result comes from understanding and interpreting the meaning of an event of human behavior interaction in certain situations according to the researchers' own perspective. Done in a reasonable setting (natural setting). The qualitative method is based on the phenomenological nature that prioritizes comprehension (DominicusDionitiusPareiraKondi, et al, 2008).

This research activity includes collecting data, analyzing data, interpreting data, and ending with a conclusion that refers to the analysis of the data (Notoatmodjo, S. 2005). Study design as follows; First, researchers ascertain that whether the formulation of the problem made is relevant for research using a phenomenological approach. Formulation of relevant research problems applying phenomenology. The research problem in this study is understood by the personal experience of the study and felt by a group of individuals and communities in the research area. Second, in compiling research problems, researchers catch the phenomenon to be questioned its meaning for a group of individuals who experience it. Third, researchers as humans leave behind their personal experiences related to the focus of their research. Fourth, phenomenological data in the form of descriptive narratives collected from stories of individuals who experience a phenomenon under study. Phenomenological research data were obtained from in-depth interviews with a group of individuals. Community leaders in the Sikka and Manggarai ethnicities are determined. as research respondents. Questions asked by a phenomenologist can vary. Typically, researchers ask about what is experienced and how the phenomenon can be experienced. Fifth, the process of data analysis is in principle similar to other qualitative analyzes, that is, the data is transcribed, then by referring to the problem formulation, the researcher does the coding, clustering, labeling thematically and makes interpretations.

\section{Discussion}

Health communication itself has various definitions depending on various points of view. In the 2010 edition of Healthy People, the definition of health communication as "the art and technique of informing, influencing, and motivating individuals, institutions, and public audiences about important health issues. The scope of health communication includes disease prevention, health promotion, health care policy, and the business of health care as well as enhancement of the quality of life and health of individuals within the community". In short, health communication is the art and technique of informing, influencing, and motivating individuals, institutions, and communities about important health issues. Its scope is prevention, health promotion, health policy, as well as improving the quality of life and health of individuals and communities (IfahInayah, 2017; ImanGunawan, 2015).

\subsection{Health Communication from Local Perspective}

Easterners' way of thinking is generally very religious, cosmic, mythical-magical, ethical and moral. The main binding of all these understandings is their view of the cosmos or the natural world. Cosmos, which means the world, is something that is created and given from a divine being. And because of this the cosmos is always associated with something that is divine, especially regarding the world order and all the people who live in it. The cosmos, because it is sacred, holy and divine and is therefore often personified as a form that transcends human and human powers, which has a human and above-human senses and to which humans must adapt, respect and worship (RifdaDiniya, 2010).

These basic demands of cosmic harmony are very religious and they must be proven in human moral-ethical attitudes; how their attitude is right and good or their behavior towards themselves and others, towards the natural world and to his belief in what he calls the highest form. Cosmic harmony in the relationship with oneself must be 
seen through a way of life and respect for oneself, attention to self and all normative elements for self-formation. In relation to relations with the natural world, this cosmic harmony must be demonstrated through the attitude of loving the world environment, natural order, loving life and not death, preserving and making this world more beautiful and what it is. Cosmic harmony with the world of the environment must also be revealed through the attitude of not making the earth barren and not bringing benefits and goodness to humans, not eradicating forests as they pleased. They assume that the spirits as an invisible form of the divine also need a quiet, safe and uninterrupted area.

Cosmic harmony in relation to the divine being must be proven by their religious attitudes and worship through rites seen as ways of relating to the divine. There are various rites made whether the rites reconcile the relationship with the divine, avoiding illness, disaster or disaster, the rite of condemnation of people who live poorly, the rites asking for divine help and support in warfare, and various other kinds of rites according to their needs and their desires. There the Divine is seen to be very anthropomorphically; that he is the Father who sees everything that happens in the human world, he can punish the guilty but at the same time reward for those who do good. He can see something secret or hidden in humans and can determine the fate of people. In this connection people speak of torture and curses or also disasters for those who do bad and blessings for those who do good.

In connection with a life free from illness believed to be the curse of the spirits or spirits of the ancestors, the Sikka-Krowe (Sikka People) on Flores Island, NTT has a set of beliefs, values, as well as verbal and non-verbal communication.

Sikka-Krowe people believe that the disease is caused by anger from spirits who live at home. In an ancient poem or mantra called "Hawong Lopa Gahu Nair" means Please Keep Away from Disease (IfahInayah, 2017), expressed both verbally and non-verbally by a shaman (rawin) who utters the spell words below while offering offerings (piong ): These are the words of the spell: "Neni ora nitu higung pitu, plawi ora noa nggarang walu, Morolo pabai meti 'uneng, harang lopa bai nai 'wateng, gea 'waung naha piong, minukawuna ha tewok, hapu watu piong pare, he tana tewok tua, nauli taming lopa beti, Ama aming lopa blara, Ohana ha memek, halarna ha blatang, Kamang lopa rudu ami 'ilurmeti, Rewenga miming marak, lana am ihokot 'uma 'ihing, kare tua dolo, Beheta hibano lalang, gole iling mapa watang". Meaning: "Ask the spirits who stay at home. Keep anger, don't save heart. Day and night, we pray. So that our bodies are kept away from all bodily diseases. Soft mats and cool fresh bales. So, we can get a garden. Even tapping tuak gets results. And we can cross the sea. And undergo hills and mountains".

If the spell is interpreted, values will be shared collectively by Sikka-Krowe people who inhabit Flores Island. The Sikka-Krowe people believe that the spirits of their ancestors lived with them in a corner of the house (higungpitu). If the occupants of the house do not pay attention to their obligation to offer offerings, the ancestral spirits become angry. Anger ancestors that cause illnesses that can be suffered by residents of the house. Garden products obtained must also be offered to the ancestors through offerings (tungpiong). If this obligation is violated, then there will be a disease suffered by residents of the house.

To overcome the illness, the head of the tribe can act as a shaman (rawin) or someone appointed by the head of the tribe to act as a shaman who casts spells while offering offerings as a form of reconciliation and can heal the sick (patient). Usually this ritual is carried out collectively, involving all members of the tribe consisting of 10-20 family heads.

In addition, the emergence of a disease in the Sikka-Krowe community (da Silva Nita tribe) on Flores Island is believed to have violated the restrictions (pire) to consume certain plants or animals. The disease that is believed to arise due to breaking this taboo is a type of skin disease that causes itching to infection. The Sikka-Krowe people on the island of Flores are forbidden to consume banyan tree leaves and dog meat (kuatbaonorakuatahu).

This belief stems from the mythological understanding of the Sikka-Krowe community whose ancestors had promised not to eat the leaves of the banyan tree when the banyan tree was originally their home. They are also not allowed to eat dog meat, because dogs are animals that have helped their ancestors in hunting and surviving. Ancestors of the Sikka-Krowe people have promised the banyan tree and the dog that they and their descendants will never eat the banyan tree leaves and dog meat. Usually in the big banyan tree in the middle of the Sikka-Krowe village there is a place to place offerings called watumahe, which are whole stones shaped like a table and some oval shaped stones placed under large trees or sacred places, which is believed to be the ancestral dwelling place.

The task of a shaman (rawin) is an important task. A shaman is usually respected by a citizen of a tribe or residents of another tribe. The greatness of a shaman is seen from how many people he managed to cure from various types of diseases. If during the treatment process, the sick person dies, it is believed that it is not because of the shaman 
who fails to provide help but because of the ancestors who wanted the death. And usually death like this is considered as a sacrifice that must be sacrificed for the safety of other tribal members.

Media that is usually used by a shaman in the treatment process, in addition to spells and offerings also a shaman uses coconut oil that is specially formulated and given additional roots, and other ingredients to treat patients or the sick. Reactions from the sick can vary. The shaman also provides a diagnosis that the pain is caused by the anger of the ancestral spirits or the mistakes of the sick, violating the prescribed restrictions. The process of delivering a message from the shaman occurs during the ritual treatment. The patient has a certain suggestion from the mantra uttered by the shaman. Mantra, offerings and concoctions used by the shaman in the ritual and the messages conveyed have a certain effect on the patient, such as: healed, still sick, getting worse and even died. If described the communication model between the dukun and the sick is as follows:
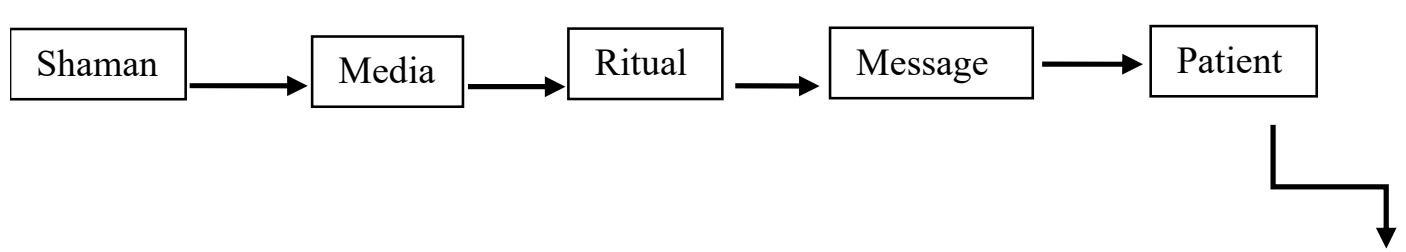

Effects / Reactions: heal, remain ill, get worse, die

According to Sereno and Mortensen, the communication model is an ideal description of what is needed for communication to occur. The model is a more simplified theory (Maulana, Arief. 2012). The communication model uses a series of blocks, rectangles, circles, arrows, lines, spirals, etc. to identify the components, variables or conditions that make up communication and suggest or describe the relationships between the components (Maulana\&Arief, 2012).

The relationship between environmental sub-systems and magical powers is also known in Manggarai. The Manggarai people who inhabit the island of West Flores know and agree with the invisible reality. Realities are like air that can notbe seen but felt its existence (MulyanaDeddy, 2007). In the beliefs of the Manggarai community, early-stage medical treatment often asks shamans they trust as a cure for the disease. The shamans or Ata Mbeko usually become the role of the healer of the disease. The period when doctors and nurses had not yet entered the interior and villages in Flores, Ata Mbeko was a mainstay to help heal the sick. Even in an era when many medical paramedics have started to do health education and medical healing, even mbeko is still the main reference for healing sick people. For the people of Manggarai, sickness is always related to things that are supernatural and supernatural. Only atambeko is able to beat the magical power (MulyanaDeddy, 2007).

In shamanistic practice, the Manggarai people chant mantras - through the wind, blow the wind on objects - water, or solid matter, - to launch an action on someone. Air, water are important elements for human life. The action can be in the form of positive (healing) activities and magic that makes people whimper in pain (Lejong, 2019).

The health communication model in the local perspective mentioned above shows a one-way (linear) communication pattern. This is similar to the widely known model, the David K. Berlo model. This model is known as the SMCR model which stands for Source, Message, Channel, and Receiver. As stated by Berlo, the source is the party that creates the message either a person or a group. Message is the translation of ideas into symbolic code, such as language or cues; a channel is a medium that carries messages; and the recipient is the person who is the target of communication (Maulana\&Arief, 2012).

Along with the times, both the Sikka-Krowe tribe who inhabit Flores Island and the Manggarai tribe have replaced the role of shamans with medical officers (nurses, midwives and doctors) who serve in every Puskesmas, Clinic and Hospital. The shamans still function to perform traditional rituals but not to cure physical ailments. This is because the belief in interference from ancestral spirits persists. So, if someone is sick, two treatments are often taken at once, namely through the shaman and through the doctor or medical officer. This belief is still very strong found in tribal members who inhabit villages where education and economic progress are still isolated. If the patient is forced to be taken to the hospital, then the shaman first makes a ritual so that the spirits of the ancestors do not follow and interfere with the healing process that will be carried out by the medical in the hospital.

Shamans who carry out rituals for healing for patients usually receive rewards (dowry) in the form of: sarong, 
tobacco, betel nut, red rooster or a pig, moke (liquer), brown rice or corn and some coins (silver or gold). Mahar must be given whether successful or unsuccessful the treatment process. If the patient is completely healed, then there is a ritual to give thanks called hu'er-blatan. In this rite, the patient's family is obliged to provide offerings and also a meal for all the tribal people who participate in the ritual. This ritual also wants to state to the public that the sick has recovered and are freed from the anger / curse of the spirits of the ancestors. So, the healing process of the sick also involves many parties including citizens collectively in a tribe that inhabits certain villages. Manggarai people used to adhere to the original religious beliefs of dynamism and animism (believe in spirits), they believed that most spirits (gods/ancestors) were present in large trees (langke), and in springs/marshes. Such trees and places are considered sacred, which has power and protection (pong). Therefore, which has strength and protection (Lejong. 2019).

When Catholicism entered and spread in the Flores Island region, the role of the shaman was increasingly pressed by the presence of the priest. Residents who become Christians are reluctant to come to the shaman again for treatment. Instead they put their trust in the priest to pray for the sick and give medicine as needed. Usually among the pastors who served as missionaries there were also those who received medical education. These priests came from the Netherlands, Germany and Poland. Rituals made by the Church are believed to go beyond rituals made by shamans. This is greatly influenced by the teachings or dogmas of the Church about grace through sacraments (Nggoro, 2016). Residents who come to the pastor may dialogue, discuss about their situation and living conditions, including the state of their health. The church through its mission then built various free Medical Clinics for small communities from the villages. In addition, in the city center, the Church is trying to build a hospital and bring in doctors and nurses. At this level, people in the Flores region began to get acquainted with various prevention efforts, health promotion, medical care, medical rehabilitation and health policy, as well as efforts to improve the quality of life and health of individuals and communities (Nggoro, 2016).

\subsection{Health Communication in Communities in Indonesia}

Health communication as an art and technique for informing, influencing, and motivating individuals, institutions and communities about health issues in modern society has become a part of life and some even consider it a lifestyle (life style).

Based on a survey conducted by Singapore's National Healthcare Group International Business Development Unit, $34 \%$ of the 300,000 patients who seek treatment to Singapore come from Indonesia. The number that is not insignificant makes the Jakarta Medical Ethics Code (MKEK) take the analysis that the phenomenon of "going to a neighboring country" is caused by the weak role of health communication of health practitioners in serving their patients (A.J. Verheijen, 1991). This of course shows the extent to which health communication can affect a person's behavior to determine where and to whom he gets treatment or care for his health.

The Professional Therapeutic Communication Trainer also revealed that in Indonesia only about $30 \%$ of doctors are rated by patients as very emotional, in the sense of having a good empathy attitude towards their patients. This is certainly different from doctors in other countries who generally have an empathetic attitude and have plenty of time to listen, so that patients do not hesitate to express deeply (Verheijen, 1991).

Health communication in Indonesia itself is actually an issue that has very good attention. Unfortunately, this attention is not balanced with good application. The tradition of health communication research carried out is still merely a thesis or thesis task with the application of research methods that are loose, inaccurate, difficult to generalize and mostly involve topics that are less strategic for the development and policy making of health communication in Indonesia (Verheijen, 1991). While health communication is influenced by trust, values, verbal communication and non-verbal communication [6]. In the context of health communication, Flores people, communication media are influenced by: (1) Trust. Residents in Maumere, Sikka, Flores, NTT Province have a habit of drinking alcoholic beverages (moke) which is believed to be a heritage that must be maintained. As a result, many men and women often suffer from pneumonia and liver disease. Doctors and health workers have difficulty convincing them that alcoholic beverages (moke) can interfere with health. In addition, the police must work hard because the level of traffic accidents and crime is often triggered by the habit of drinking the moke; (2) Value. The dominant concept found in the culture of Flores is the concept of collectivism (Collectivism). This is triggered by natural factors that are geographically hilly, with areas of savanna that are not too broad for traditional livestock business other than livelihoods in agriculture with shifting cultivation systems. The pattern of collectivism is felt more strongly in the culture of Flores people because it can unite the community so that they (members of certain sub-cultures) are able to survive and are also able to overcome challenges, threats and disturbances especially those originating from nature. This is why people believe in the ability of a shaman and there is a sense of doubt and even fear of strangers. People in the interior of Flores Island feel more comfortable seeing a shaman or priest rather 
than seeing a doctor; (3) Verbal communication. Language is relative. Words cannot be translated into other languages with the same accuracy. Differences in understanding of words will be even more complicated if people use different mother tongues. For example, common colds are not known in the West. Likewise how to treat it by scraping the body with coins. An anecdote describes: an Indonesian executive who flew abroad whose body was reddish after being scraped off was released by a white terrorist group who thought he was suffering from an infectious disease; and (4) non-verbal communication. In Indonesia, nodding your head doesn't always mean yes and shaking your head doesn't always mean no. Indonesian doctors must critically interpret this cryptic patient message. For example, if the doctor expects the patient to come back to see him next week, after the doctor gives the medicine, nodding the patient's head does not automatically mean consent. The patient nods, but he may not intend to return to see the doctor. Whereas further consultation is important for patient health. Another example from Flores, when the government intensified the Family Planning program in the village, a problem arose when the officers misunderstood the use of condoms displayed on the index finger. As a result the husband was confused that what had been done according to instructions turned out to make his wife pregnant again. Elsewhere, a similar case also occurred but using banana props which happened to be presented to the Family Planning officers who came. Because they try to maintain politeness, the officer does not clearly state that condoms must be placed on the husband's genitals.

The psychological touch aspect becomes another part of the patient's needs. Research in health communication shows that patients' needs for psychological touch have not been met by medical professionals. The pat and smile of a doctor and nurse produce a positive effect on patients who are hospitalized (Venus \& Maulana, 2012). But of course, medical professionals also need to pay attention to the shape, frequency, location of touch, gender, culture, and religion of the patient so that the patient feels comfortable with the touch.

Hand signals can be a source of problems. A medical professional who calls an adult patient in Ethiopia or in East Africa with a finger has made a big mistake. Because in that country, these cues are only used to call children or dogs.

Spatial planning also needs to be considered. Doctor Abraham White conducted an informal experiment to find out whether the table that restricted the doctor and his patient affected their consultation. The doctor found, when the dividing table was removed, $55.4 \%$ of the number of patients sat relaxed. If the table is in place, only $10.8 \%$ of the number of patients who sit relaxed (Knapp \&Judithl, 2002).

\section{Conclusion and Recommendation}

Health communication in Indonesia is not yet part of modern health services. Many medical staff have not yet realized the importance of building effective local culture-based communication from patients. Medical staff need to learn local culture-based health communication in order to assist the modern health service process.

In the future, health communication experts need to think about to incorporate strategies and development of local culture-based health communication in the medical care of patients in Indonesia.

\section{Research Limitations}

This research uses descriptive method, the possibility of experiencing a bias in connecting one fact with other facts in a social reality composed of various factors, multidimensional, and interrelated aspects merges. However, researchers believe that data and information are guaranteed accuracy and validity because researchers are also part of the population in the study area who experience everyday phenomena. If there are other researchers who want to explore deeper about culture-based health communication, please use this research data and information as basic knowledge before going to the research field.

\section{Competing Interests Statement}

The authors declare that there are no competing or potential conflicts of interest.

\section{References}

Anonim. (2004). ANAXIMENES and their applications in Manggarai Cosmology. Retrieved 29 November 2019, from http://filsafatmanggarai.blogspot.com /2014/01/anaximenes-dan-aplikasinya-dalam.html

Anonim. (2018). Flores Tribal Local Belief. 2018. Retrieved 30 November 2019, from https://kepercayaanlokal2018saa4bkelompok2.blogspot.com/2018/ 04/kepercayaan-lokal-suku-flores.html

Dominicus, D. P. K., Alexius, B. P., Lewis, E. D., \& Oscar, P. M. (2008). Sikka Kingdom Story: a joint edition of two handwritten sources and the history of the Sikka Kingdom. Retrieved January 3, 2020, from https://www.worldcat.org/title/hikayat-kerajaan-sikka-edisi-gabungan-dari-dua-tulisan-tangan-tentang-sumb 
er-dan-sejarah-kerajaan-sikka/oclc/311800240

IfahInayah. (2017). Cultural Relations in East Nusa Tenggara and Health.Retrieved 30 November 2019, fromhttps://www.scribd.com > document > Artikel-Hubunga...

Iman Gunawan. (2015). Qualitative Research Methods.State University of Malang.Retrieved 30 November 2019, fromhttp://fip.um.ac.id/wp-content/uploads/2015/12/3_Metpen-Kualitatif.pdf

Lejong. (2019). Ata MbekodanMbeko; About Traditional Healing Practices in East Manggarai. Tabeite.com. Retrieved 30 November 2019, from https://tabeite.com/ata-mbeko-dan-mbeko-tentang-praktikpenyembuhan-tradisional-di-manggarai-timur/

Mark, L. K., \& Judith, A. H. (2002). Nonverbal Communication in Human Interaction. Retrieved December 9, 2019 from https://books.google.co.id/books/about/Nonverbal_Communication_in_Human_Interac.html?id=Rw_vkQE ACAAJ\&redir_esc $=\mathrm{y}$

Maulana, A. (2012). Development of Health Communication Needs To Be Improved. Retrieved 12 October, 2012, from http: // www.unpad.ac.id

Mulyana, D. (2007). Communication Studies: An Introduction.Bandung: RemajaRosdakarya.Pp. 134.

Nggoro, A. M. (2016). Manggarai Culture at a Glance. Retrieved 29 November 2019, from http://daonlontarbooks.blogspot.com/2017/06/budaya-manggarai-selayang-pandang.html

Notoatmodjo, S. (2005).Health Promotion Theory and Application. Publisher:RinekaCipta. Jakarta. 2005.

Rifda, D. (2010). Factors Affecting Health Communication.Retrieved January 05, 2020, from http://satucintadini.blogspot.com/2010/10/model-komunikasi-kesehatan.html

Venus, A., \& Maulana, A. (2012). Development of Health Communication Needs to Be Enhanced.Retrieved 10 November 2019 ,

from http://www.unpad.ac.id/2012/10/pengembangan-komunikasi-kesehatan-perlu-ditingkatkan/

Verheijen, A. J. (1991). Manggarai and Supreme Being. Published 1991 by Indonesian Institute of Sciences andLeiden University. Retrieved 29 November 2019, from https://www.goodreads.com/book/show/ 11422023- manggarai-dan-wujud-tertinggi

Wikipedia. (2020). Flores Island, Tribes and Languages. Diaskes 21 February 2020. Retrieved from https://id.wikipedia.org/wiki/Pulau_Flores

\section{Copyrights}

Copyright for this article is retained by the author(s), with first publication rights granted to the journal.

This is an open-access article distributed under the terms and conditions of the Creative Commons Attribution license (http://creativecommons.org/licenses/by/4.0/). 